But even when science has done its all to minimise such perils, eternal vigilance will remain (as now) the prime condition of 'safety'; and the official inquiry into the recent Gresford disaster left an uneasy feeling that all is not as it should be.

Seeing that the Commission is charged with the duty of inquiring into the health, as well as the safety of mine-workers, the non-inclusion of any physiologist in its membership is to be severely criticised. The underground conditions of such hard and sustained manual work as miners have to perform call for greater scientific investigation and supervision than have yet been given to them ; and there are many problems in sanitation and nutrition upon which only physiologists are competent to pass judgment.

\title{
Cultivation of the Unfit
}

T ORD DAWSON OF PENN, like Sir Arthur 1 Keith, is one of the few scientific men who have the rare courage of forcing the public to listen to unpopular truth. Just as Sir Arthur Keith has repeatedly pointed out that war is not due to a perversion of human nature but is the inevitable result of increasing population and race pressure and is the means by which Nature decides which race shall "inherit the earth", so Lord Dawson, in his recent address to the York Medical Society entitled "Medical Science and Social Progress", has-not for the first timeraised the question of whether our philanthropic efforts to save the lives of all babies, however weakly, may not serve as actual hindrances to the future well-being and progress of our race. Lord Dawson asserts that, in the sixty-four years between 1870 and 1934, the infant death-rate has sunk from 156 to 60 per thousand, and of children under five years of age from 68 to 18 per thousand. The population during this time has increased by about fifty per cent, and the fact that there has not been a more spectacular increase is solely due to the concomitant fall in the birth-rate.

Amongst the lower species of animals, we may, without serious error, assume that the birthrate remains approximately constant; and the recurrent plagues of over-population are brought back to normal dimensions by the increase (1) in predatory animals, (2) in the incidence of disease. Only the most vigorous members of the species survive, and these are the worthy progenitors of the next generation. If this weeding out of the unfit is prevented, there follows a deterioration of the whole species. Two examples of this on a gigantic scale are sufficiently interesting to be recorded here. The first occurred in Switzerland : the second in New Zealand. The Swiss established a park for the preservation of the chamois, from which wolves were carefully excluded. As a result, more and more weakly and deformed specimens appeared amongst the stock until at last the Swiss introduced a certain proportion of wolves; these found in the weaker chamois an easy prey, and the surviving stock recovered its vigour and fine appearance. New Zealand has always been an ideal field for rearing mammals, because in it there are no indigenous predatory animals whatever. The Scottish settlers longed for the red deer of their native highlands, so these were introduced and let loose upon the New Zealand hills, where they flourished exceedingly. But soon the herds became polluted by misshapen specimens, and in the end wolves had to be imported to weed out the unfit.

Lord Dawson, therefore, poses the question: In adopting elaborate and costly social services in order to keep every baby alive, are we not preserving as progenitors of the next generation people who-morally, mentally, and physicallyare just as unfit as the deformed chamois and deer? But our sentimentalists tell us that the population is increasing ever more slowly and will soon be stationary; so that there is no occasion for worry. But the birth-rate is falling, if we may so phrase it, at the wrong end. In the middle of the nineteenth century the commercial and professional classes had large families, and the numerous children of clergymen were proverbial. The minimum size of family required to maintain a population constant is four ; for allowance has to be made for the sterility of some couples and the premature death of some children. The average size of family among both doctors and clergymen is now two, so that neither of these classes is maintaining itself by reproduction.

It would, however, be a libel to accuse the working-classes as a whole of over-breeding. When 
the leaders of the skilled trades unions are bargaining with the employers for a 'living' wage they do so on the basis of the support of a man and his wife and three children - a most modest and reasonable demand. It is when we come to consider unskilled labour that we find reckless breeding still going on. Dock labourers and miners figure prominently in the over-production of children, and it is worthy of note that in both groups there is a large proportion of the Iberian element in our population from Wales and Ireland. But this level also receives social failures from the higher grades; and these, according to Lord Dawson, include a large proportion of mental defectives - not of the extreme type, but just able to earn a living in the poorest paid occupation. These make most undesirable parents, and they propagate more defectives for the next generation. It costs, as Lord Dawson informs us, six times as much to care for and educate a mentally defective child as to educate a normal child in an elementary school, and when the task is complete the defective remains a defective.

How is this undesirable state of things to be remedied? Lord Dawson gives two answers-first, by the spread of the knowledge of the means of birth-control and secondly by voluntary sterilisation. Knowledge of birth-control is spreading: the only objection is that it is used by the wise and prudent and ignored by the wicked and reckless, and it is the reproduction of this class that we wish to prevent. As to voluntary sterilisation, which is advocated by Lord Dawson, we do not share his confidence in this as a cure. Sterilisation is a mutilation to which few people will consentin California it is imposed only by offering it as the alternative to perpetual imprisonment. Moreover, the tests for mental defect are by no means so reliable as Lord Dawson seems to suppose. Gross mental defect can, of course, be recognised, but the sufferers are unable to care for themselves and are confined in institutions. Where the line between a high-grade defective and a consummate fool is to be drawn no one can say.

There is only one remedy for the over-production of children that we can see, and it is very unpopular, so that it will probably be some time before the necessity for it forces itself on the public mind. This is compulsory sterilisation as a punishment for parents who have to resort to public assistance in order to support their children. Bishop Welldon recently mentioned the case of a worthless pair in Durham, both of the tramp class, whose only means of support was the dole and who had no less than seventeen children, and every time a new baby arrived the maternity benefit was spent on drink. What weight would prudential arguments in favour of sterilisation have in a case like this ? In the eighteenth century, as Miss Buer has shown, these surplus children were swept away by disease. In 1730, out of every five children born in London three died before attaining the age of five: now we carefully preserve all alive and in so doing we have prepared for ourselves a terrible problem which we or our successors will have to face.

E. W. M.

\section{The Astronomer Royal Surveys the Cosmos}

\section{Worlds Without End}

By Dr. H. Spencer Jones. Pp. $x \nabla+262+32$ plates. (London: English Universities Press, Ltd., 1935.) 5s. net.

THE Astronomer Royal has written an exastronomical knowledge, in its broadest outlines, at the present day. This is a book intended for perusal by the general reader, to whom we recommend it with the utmost cordiality and confidence. A work of this kind must avoid the heavy technicalities of modern science if it is to be successful in providing pleasurable instruction and authoritative information to the reader for whom it is designed. The author has steered clear of pitfalls of this nature, and the result is a smoothly-written description of the fruits of astronomical investigations with, here and there, a pleasant excursion into the recent and remote history of the science.

The author's plan is to begin with a brief account of the earth and work outwards into space, finally reaching the spiral nebulæ-or "celestial catherine. wheels" as he calls them. In the final two chapters, the theoretical astronomer and the cosmogonist come into their own, and Dr. Spencer Jones gives in these pages an admirable résumé of the theoretical researches of Eddington and Jeans. As he says: "The theoretical astronomer uses the material which has been provided by observations ; 